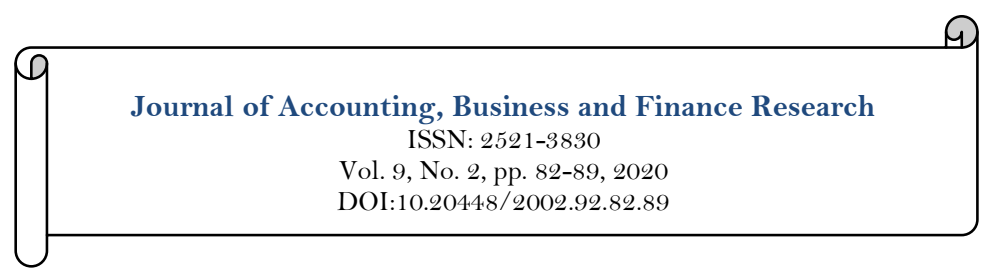

\title{
Government Size, the Composition of Public Spending and Economic Growth in Netherland
}

\author{
Gilbert Nartea ${ }^{*}$ \\ Jacqueline Hernandez ${ }^{2}$ \\ ${ }_{1,2}^{1,}$ University of Amsterdam, Netherlands \\ Email: GilbertNa4532@yahoo.com
}

\begin{tabular}{|c|c|}
\hline Abstract & \\
\hline $\begin{array}{l}\text { The performance of the fiscal policy is influenced significantly by the } \\
\text { relationships and associations among the governmental size, the composition } \\
\text { public and private spending and the economic growth of a country. The } \\
\text { primary goal of this research study is to evaluate the impact of these factors } \\
\text { and to evaluate the significance of these factors in the economic growth of the } \\
\text { Netherlands. The economy of Netherlands is characterized as the 17th } \\
\text { largest in the world and it presents stable and sustainable growth. In this } \\
\text { altercation the researcher aimed to evaluate the significance of the } \\
\text { governmental spending and size. For this purpose, the researcher used the } \\
\text { data from } 2004-2014 \text { from the } 12 \text { provinces of Netherlands. The data was } \\
\text { subjected to a unit root analysis so that the stationarity properties of the panel } \\
\text { data can be evaluated. The unit root test results showed that the variables } \\
\text { were stationary at I(O). In order to abstain from the endogeneity issues that } \\
\text { can be present in such types of datasets the researcher used level and per } \\
\text { capita variables as a robustness evaluation. The empirical framework was } \\
\text { based upon the Cobb-Douglas production function and used the modern } \\
\text { CES substitution elasticities to compute as the inputs of private capital and } \\
\text { government spending in the production function. The nonlinear least- } \\
\text { squares regression estimation method was used to evaluate the impact of the } \\
\text { variables upon one another. The results indicate that the public investments } \\
\text { and current governmental disbursements are conjoined in order to account } \\
\text { for the inflexibility of the communal budget. Moreover, the governmental } \\
\text { spending was found to be greater than 85 percent indicating that the } \\
\text { provincial sectors are focused upon the stimulation of the economy. }\end{array}$ & $\begin{array}{l}\text { Keywords: } \\
\text { The Netherlands } \\
\text { Governmental expense } \\
\text { Economic growth. } \\
\text { Licensed: } \\
\text { This work is licensed under a } \\
\text { Creative Commons Attribution } 4.0 \\
\text { License. } \\
\text { Publisher: } \\
\text { Scientific Publishing Institute } \\
\text { Received: } 29 \text { April } 2020 \\
\text { Revised: } 8 \text { June } 2020 \\
\text { Accepted: } 22 \text { June } 2020 \\
\text { Published: } 20 \text { July } 2020\end{array}$ \\
\hline
\end{tabular}

Funding: This study received no specific financial support.

Competing Interests: The authors declare that they have no competing interests.

\section{Introduction}

The objective of the government of the Netherland is to promote economic growth as well as the social development of it, but it is difficult to conclude the impact of increment in public intervention on economic performance (Balsalobre-Lorente, Shahbaz, Roubaud, \& Farhani, 2018). It is well known that the economic development of the Netherland is very important for the determination of its success, but the structure of the economy and the distribution of income is also considerable terms regarding economic development (Pradhan, Dash, Maradana, Jayakumar, \& Gaurav, 2017). Cooper (2020) said that government size is critical for the development of the economy as the changes made in the growth of the government tend to affect the changes in the economy. The composition of public expenditure also results in increasing the economic development of the Netherland as it is positively related to the advancement of the economy, and it can be determined with the help of fiscal policy (Aparicio, Urbano, \& Audretsch, 2016). 
The theoretical and empirical efforts and literature have dedicated a significant amount of work to evaluate these problems and issues, and Divino, Maciel, and Sosa (2020) for instance completely evaluated the exclusive influences of government spending and policies on the overall economic development and productivity of the country. In a pioneering effort, Bouakez, Guillard, and Roulleau-Pasdeloup (2016) also suggested a model evaluate the direct connection between the composition of public expenditure (PE) and economic development. This all indicates that much of the efforts have been completed in the past few years regarding government spending and its impacts on the overall economic situation of the country (Facchini \& Seghezza, 2018). Nonetheless, the research has not been conducted regarding Netherland and its economic growth (EG) conditions. None of the previous work has explained the impact of government size on Netherland economy situation and development. Thus, the given study is new and justified to understand the influence of GS on economic development.

\subsection{Research Objectives}

In the line of the above justification statement, the major purpose, and objective of the given research are to evaluate the interdependence between the optimal size of the government (OSG), optimal configuration, and composition of the aggregate government spending (AGS) and economic growth. Another objective of the given paper is to extend the existing literature proposed by different past researches to indicate how OGS and AGS rely on the framework's structural specification. There is clear evidence of the detailed discussion about the issues and impacts of the decisions of the government, their policies, and the implementation of new strategies to make the economy of the country very progressive and analyses the sources and expenditures equally with a perfect balance and ratio. But a wide gap that all these studies committed was regarding evaluating the data of the government size, composition, and spending in public growth. The study has selected a very sensitive issue to analyze in detail. This study is very helpful for the government machinery to evaluate the aspects that can play a major role and enhance the performance and value of the projects defined well for public growth. The subject has a universal appeal.

The rest of the paper is framed as follows; the upcoming section mainly gives the model summary and outcomes and the empirical proof for the Netherland states and cities which is reported and discussed in the third section, and finally, the final section is dedicated to the final and concluding statements and remarks.

\section{Literature Review}

\subsection{Theory of Public Expenditure}

According to Michaillat and Saez (2019) public expenditure (PE) is the spending develop by the government of a nation on collective demands and some basic needs. In light of this theory, until the $19^{\text {th }}$ century, public spending (PS) was restricted as laissez-faire theories believed that capital left in private authorities could bring significant returns and development. Later on, in the $20^{\text {th }}$ century, Burlon (2017) argue the part and role of PS in determining the levels of income and distribution in the overall development. Since then, government spending has indicated as increasing trend, and sources of government revenues mainly including taxes and non-tax revenues (Bove, Efthyvoulou, \& Navas, 2017). Many theories and models of taxation and spending exist in public economics but the given theory is best suited to support as well as understand the proposed framework of the given study. According to the given theory government at all levels tries to raise revenue and its optimal size and role in the overall economy. Moreover, the given theory also states that the details of taxation are majorly guided by two principles; who will benefit and who can pay. According to Biswas and Chaudhuri (2018) PE means spending on the development and non-development practice such as the development of roadways and dams and other practices that directly influence the entire economic development. Furthermore, this theory also states that the correct use of PE can be a useful and significant economic policy strategy for governments to improve the current economic situation of the country (Das \& Kar, 2016). Besides, fiscal policy can be defined as the use of public spending (PS) and taxation as a direct process to influence the economy of the nation. Fiscal policy (FP) can mainly be incorporated by governments to stimulate the economic indicators during a recession such as according to Meričková (2017) an increase in PE and spending directly increases needs and demand for services and goods, which can mainly help increase output and employment and this lead to significant EG.

\subsection{The Relationship between Government Size and Economic Growth}

The study describes the government size and economic growth and this all depends on the service quality and effective system of tax revenue .empirically, the results are controversial (Asimakopoulos \& Karavias, 2016). The government size depends on the proper setup and system of policies and strategies to maintain the system with proper rules and regulations to make it more effective (Shittu, Hassan, \& Nawaz, 2018). Chen (2020) in a study demonstrates that the proper setup of taxes and revenue impacts the strength of the government size and the EG also indicates that the government policies are running with the best options and accepted by the organizations and firms very openly and these policies play a positive role in making the economy of the country very strong and efficient to meet the financial crises and challenges with a positive mind and the members of the economic policymakers are ready to face such challenges and make their best 
efforts to cope the challenges. The relationship between government and the EG as the expenditures by the government has created a kind of inconvenience and economic downfall for many countries (Duasa, 2018). This downfall in the economic growth of many countries brought about a change. The economic growth increases when the government makes such policies that meet the challenges of the economic demand of the country. Good parameters, structure systems, policies, and strategies play a very wide role in the EG and the economic development of the government also. The study evaluates the relationship between government size and economic growth (Bergh \& Henrekson, 2016). The main cause of the negative impact and relationship between the two variables is very wide. The research includes a very detailed evaluation of the government size, the government expenditures to the total output of the economy in other words GDP as the scale of the measurement of the government. The fact is that the scope of improving the economy of the country the change in government size is very compulsory and crucial (Alarlough, Rabiei, \& Shoorkchal, 2017). According to Hajamini and Falahi (2018) The governess with good economic growth and a very positive output ratio proves a very strong economy but the government size involves all the expenditures that lead the economy in such a way where the public faces a high ratio of prices, unemployment, the negative impact of such policies creates a negative impression and the public remains unrest and never trusts the government policies. This uncertainty and the high price of ordinary life items create a kind of controversy and the firms and organizations of the foreign countries feel it impossible to move in such countries (Wadho \& Ayaz, 2018). The economy of such countries faces a lot of difficulties and crises. The size of the government and the policies should be that may become very positive and fruitful for economic growth and friendly so that the economy of the country may become prosperous and significant. Another study by Magazzino and Forte (2016) also examined that the economic growth of the country impacts and plays a very sustainable performance in making government size increase. Therefore, the given research effort hypothesized that;

H1: There is a direct and significant relationship between the optimal size of the government and economic growth.

\subsection{The Connection between the Composition of Public Spending and Economic Development}

Public spending according to Alimi (2020) is government spending and expenditure and it is mainly incurred by Central and State governments. The overall PE is mainly incurred on several activities and procedures for the welfare of the public and the EG, majorly in developing nations and states. In modern economic settings and activities, the correct composition of PE and PS has to play a significant role in improving the existing situation of the economy (Lupu \& Asandului, 2017). According to Ashwani and Sheera (2017) the significant and efficient composition of PS can promote EG such as promoting economic development and to promote trade and commerce. The composition of PS refers to the systematic arrangement and framework of several items on which the government incurs PE. according to PS can be composite and classified as follows; capital and revenue spending, development and non-development spending plan, and non-plan spending and expenditure (Meričková, 2017). Capital and revenue spending of the government refers to that spending which results in the creation of fixed assets and they are mainly in the form of investment, according to Keefer, Scartascini, and Vlaicu (2020) they add to the net productive assets of the economy. As described by Balaev (2019) explained that the capital spending is an investment spending and also a non-recurring type of spending for example spending on agriculture as well as industrial development, public organizations and irrigation dams are all capital spending that directly influences the economic situation of the nation. Revenue expenditure is the process of spending money on civil rights and administrations such as the health and education sectors.

Spending on infrastructure development, public organizations, and firms or growth of agriculture improve the overall outcomes of the department as well as helps in the development of that sector also. Commonly, the continuous improvement in the entire economy and bring improvement to the situation of the economy and government composition. Thus they are composite as productive spending and all these development spending promote effective EG and development. Furthermore, according to transfer spending also impact EG such as that kind of spending against there is no corresponding transfer of actual resources such as goods and services. Such kind of spending mainly includes public spending on national old pension processes, interest payments, unemployment allowances, subsidies, and welfare advantages to weaker communities (Dudzeviciute, Simelyte, \& Liucvaitiene, 2018). By composing such spending the government does not get anything in return, but it adds value to the entire EG and welfare of the public. The above theory of PE supports the given relationship between compositions of PS and EG, as the theory state that well organized and composed PE leads to favorable EG. Moreover, it has also illustrated that the public spending depends on the aggregate of government elasticity and distribution of wealth, as according to cob Douglas case, the composition of public spending completely depends upon different parameters of public investment. Thus, based on the above entire discussion the given research study hypothesized that;

H2: There is a direct and positive connection between the composition of public spending and economic development.

\section{Methodology}

The methodology is based upon the framework defined by Devarajan, Swaroop, and Zou (1996) whose baseline model is extended in this study. The model is being extended in order to consider a general CES 
(constant elasticity of substitution) system for the cumulative expense structure of the government as well as the economic production technology by proposing some restrictions upon the values of the parameters. Moreover, the technological progress is also considered as a cumulative CES production function. Therefore, the production function being estimated in this study is dependent upon the stock of capital $\mathrm{k}$, the aggregate spending of the public indicated by $\mathrm{x}$ and the technological progress. The estimation is based upon the nonlinear least squares' method, where the equation for the CES evaluation is presented in Equation 1. The basic aim is to characterize the parameters that will aid in the computation of the optimum governmental size, economic growth, substitution and other optimum associations guided by previous empirical findings. The study employs the use of panel data and in this environment the CES production function estimate or equation is defined as follows;

$$
y_{j t}=A_{j t}\left[\alpha k_{j t}^{-C}+(1-\alpha)\left[\left(1-\eta_{1}\right) g_{j t}^{-c_{1}}+\eta 1 g_{2 j t}^{-c_{1}}\right]^{\frac{c}{\varepsilon_{1}}}\right]^{-\frac{1}{\varepsilon_{1}}}+\varepsilon_{j t}
$$

In the above stated equation, the distribution parameters are defined by the term $\alpha$, it defines the share of the private capital held in the production; the term $(1-\alpha)$ represents the share of the aggregate governmental spending in the overall production. Moreover, the term $\eta 1$ is the overall share of the current spending and $(1-\eta 1)$ represents the share of the public investments in the aggregate governmental expenditure. The terms $\zeta$ and $\zeta_{1}$ are substitution parameters which are used to yield the elasticities of the substitution and $\varepsilon_{j t}$ is the error term which is based upon the homoscedasticity assumption and it is independent of the dependent and independent variables and is distributed normally. The technological progress in each state is represented by $\mathrm{A}_{\mathrm{jt}}$. Following the directions presented by Duffy and Papageorgiou (2000) the technological progress is modelled as follows;

$$
A_{j t}=\exp (\gamma p i+v t)
$$

In the above expression the term pi refers to a explicit factor encapsulated to account for the heterogeneity that may result from the technological progress across the states of the Netherlands and $t$ is used to explain the impact of time trend so that a stable technological growth rate can be accounted by $\mathrm{v}$, which occurs as a commonality among the states. The main benefit of this method is that it accounts for both factors of the technological progress, which is specified by the common trends and the state specific results as well. The increasing circulation of patents across the provinces of Netherlands is utilized to generate a dummy variable for the $\mathrm{i}^{\text {th }}$ group that represents the province with the minimum number of patents. These provinces are characterized by a simpering technological development and have a lesser growth activity than the average value when $\gamma<0.12$. An assumption contesting that the exogenous technological development may possibly be growing progressively over time across the provinces of Netherlands, v valuates the stability of the growth rate in the technological progressions over time. At last as robustness checks the variables have been considered in their actual and per capita states and are estimated with and without the technological progress.

Thus, the following models are estimated;

Model 1: without incorporating the values of the technological progress, $\mathrm{A}_{\mathrm{jt}}=1$ for all considered states of Netherlands

Model 2: inclusive of technological progress, estimated at $i=4 \%$ of the Netherlands states designating the minimum listed patents in the time series under consideration

Model 3: analogous to model 1 but estimated on the basis of the per capita variables

Model 4: analogous in composition to model 2 but estimated on the basis of the per capita variables.

\subsection{Data}

The study employs the use of a balanced panel data consisting of 12 provinces from the Netherlands for the period from 2004-2014 with annual data totaling about 200 observations for each variable. The nominal variables have been deflated using the consumer price index (CPI) calculated and maintained by the World Bank database WDI and has been used as an inflation adjusting technique by the central bank of Netherlands. The following variables are used in the study

y: The gross domestic product of each province of the Netherlands

g1: The governmental spending in capital by each of the states provided by the provincial area plans, this value includes the investment expenditure and production of durable goods and excludes the debit

g2: The current governmental spending in each of the provinces, excluding the expenditures on salaries, consumption of services and goods and interest rate payments. The source is the provincial area plans released by the government

$\mathrm{k}$ : The stock of the private capital invested in each of the Netherlands province, calculated in accordance with the method proposed by Sanches and Rocha (2010)

The constituents of the technological development of the Netherlands province are evaluated on the basis of the listed patents provided by the directory of intellectual property (WIPO). A dummy variable has been created in order to account for the provinces that represent a low number of registrations. 


\section{Results}

First of all, the panel data is subjected to a unit root analysis. If the variables of Equation 1 present the issue of non-stationarity and show evidence of presence of unit root, then the panel data has to be evaluated for the presence of nonlinear cointegration so that the false and misleading regression results and estimations that arise as a result of unit roots can be abstained from. The tests proposed by Levin, Lin, and Chu (2002) and Im, Pesaran, and Shin (2003). Conversely although informative these tests do not consider the presence of crosssectional correlations which are probably present in our dataset as it represents sub-national governments the second generation unit root tests proposed by Hadri (2000) and Pesaran (2007) have also been applied. These tests take the cross-sectional dependence into consideration and produce robust results for heterogenous panels. The results of the unit root test for the variables at level as well as the per capita variables have been presented in Table 1. The results indicate that the panel is stationary at standard at the 5 percent level of significance. Thus, the variable relations can be estimated, and we do not have to perform the cointegration test.

Table-1. Unit Root Test Results

\begin{tabular}{|c|c|c|c|c|}
\hline \multicolumn{5}{|c|}{ Level Variables } \\
\hline Tests & $\mathbf{y}$ & $\mathbf{k}$ & g1 1 & ge \\
\hline $\mathrm{ADF}$ & $-3.94 * *$ & $12.09^{* * *}$ & $-2.86 * *$ & $--3.70^{* *}$ \\
\hline LLC & $-24.62^{* *}$ & $-20.79^{* *}$ & $-19.62^{* *}$ & $-20.57 * *$ \\
\hline IPS & $-3.46^{* *}$ & $-4.68^{* * *}$ & -1.12 & $-2.76^{* *}$ \\
\hline HADRI & 1.02 & -3.47 & 1.28 & 0.65 \\
\hline PESADF & $-71.88^{*} *$ & $-43.13^{* *}$ & $-1.74^{*}$ & $-9.23^{* *}$ \\
\hline \multicolumn{5}{|c|}{ Per Capita Variables } \\
\hline ADF & $-2.44^{* *}$ & $-12.07 * *$ & $-6.95^{* *}$ & $-1.86^{*}$ \\
\hline LLC & $-84.26^{* *}$ & $-6.71^{* * *}$ & $-32.71^{* *}$ & $-81.85^{* * *}$ \\
\hline IPS & $-3.86^{*}$ & $-5.34^{* * *}$ & $-1.68^{*}$ & $-2.84^{* *}$ \\
\hline HADRI & 0.17 & -3.54 & 1.31 & 0.75 \\
\hline PESADF & $-6.13 * *$ & 0.60 & $-24.98 * *$ & $-10.51 * *$ \\
\hline
\end{tabular}

The estimation process is based upon the nonlinear estimation technique proposed by Davidson and MacKinnon (2004). The process involves the adjustments of the nonlinear equation defined previously on the basis of a WLS, weighted least squares regression that evaluates the vector parameters effectively. The software Stata was used to create a variance/covariance matrix required for the weighting progression. At every step a parameter vector is calculated, and a standard is employed. The process is iterated until complete coverage or all vector parameters are computed. This technique necessitates the use of initial values for the parameters of the model. Thus, $\alpha=0.31, \zeta=0.1, \zeta 1=0.1, v 1=0.6$ and $\gamma=0.0001$ was set. In order to account for the individual heterogeneity of the provinces of Netherlands, a correction was performed in the matrix for the evaluation of robust standard errors.

Table-2. Coefficients.

\begin{tabular}{|c|c|c|c|c|}
\hline Parameters & 1 & 2 & 3 & 4 \\
\hline$\alpha$ & $\begin{array}{c}0.661^{* * * *} \\
(0.073)\end{array}$ & $\begin{array}{c}0.649^{* * * *} \\
(0.062)\end{array}$ & $\begin{array}{c}0.695^{* * *} \\
(0.076)\end{array}$ & $\begin{array}{c}0.679^{* * * *} \\
(0.059)\end{array}$ \\
\hline$\zeta$ & $\begin{array}{c}-0.285^{* * *} * \\
(0.065)\end{array}$ & $\begin{array}{c}-0.280^{* * *} * \\
(0.055)\end{array}$ & $\begin{array}{c}-0.302^{* * *} * \\
(0.067) \\
\end{array}$ & $\begin{array}{c}-0.329 * * * \\
(0.059)\end{array}$ \\
\hline n 1 & $0.886^{* * *}(0.131)$ & $\begin{array}{c}0.842^{* * * *} \\
(0.143)\end{array}$ & $\begin{array}{c}0.989 * * * \\
(0.042)\end{array}$ & $\begin{array}{c}0.861^{* * * *} \\
(0.086)\end{array}$ \\
\hline$\zeta 1$ & $\begin{array}{c}0.355 \\
(0.731)\end{array}$ & $\begin{array}{c}0.211 \\
(0.718)\end{array}$ & $\begin{array}{c}1.271 \\
(1.529)\end{array}$ & $\begin{array}{c}0.204 \\
(0.341)\end{array}$ \\
\hline$\gamma$ & - & $-0.624 * * *(0.076)$ & - & $0.681^{* * *}(0.102)$ \\
\hline R-squared & 0.966 & 0.971 & 0.967 & 0.991 \\
\hline Adjusted R-squared & 0.965 & 0.970 & 0.968 & 0.991 \\
\hline
\end{tabular}

The outcomes are reported in Table 2 , it is clear from the evaluations that the coefficients are significant on the 1 percent level of significance. There can be an issue of endogeneity due to the presence of reverse causality between the output and the governmental spending and the additional characteristics associated to the evaluation of the production function. In order to deal with this problem and as an evaluative technique the FMOLS estimation with linear Kmenta function was performed as well. The results were found to be in line with the results presented in table 2 . The parameter $\mathrm{v}$, which takes the impact of the technological progress under consideration wasn't found to be significant in any estimation method. This outcome is probably manifested due to the short time period being considered and the heterogeneity of the Netherlands provinces. 
Therefore, the effect of the time vector hasn't been reported in the results and only the state specific factor values for $\gamma$ have been reported. The models 1 and 2 refer to the variables at their level states and the models 3 and 4 compute the variables in their per capita stage. The overall share of the private capital was estimated to be greater than 64 percent in all of the models insinuating the importance of the private capital spending. The computed values for $\zeta$ are negative and indicate that the cumulative governmental expenditure and the reserved capital or the capital manifested by the public is alternative inputs in the production input. This finding implies that the ratio of these quantities in the production changes more uniformly and consistently to any other change in the ratio of the marginal products; however the direction couldn't be identified. The governmental spending is estimated to be greater than 85 percent in all models, indicating that the government is currently involved in spending a larger fraction of the budget in current spending rather than in investment. The coefficient $\zeta 1$ wasn't found to be significant at the 5 percent level. Moreover, the r-squared and adjusted r-squared values of the models are significant and account for the explanation of the variance of the model.

\section{Discussion}

The main objective of this study was to empirically investigate the relationship between the government spending, government size and the economic growth of the Netherlands. The discussion on the relationship of government spending and size and economic growth has been the focus of attention in developing and emerging countries (Akram \& Rath, 2019; Gnangoin, Du, Assamoi, Edjoukou, \& Kassi, 2019). The study by Nirola and Sahu (2019) evaluated the impact of governmental size on the economic growth across 23 states of India, ranging for the period between 2005 and 2014. The study applied the methods of the pooled OLS and the random effects model in order to evaluate the impact of governmental size on the state centric economic growth. The results in line with recent studies showed that a bigger governmental structure is detrimental for the state centric growth of the economy. Moreover, the impact of the negative growth is detrimental upon the quality of the institutions of the states. The study in line with our results also pointed out that the reduction in the non-developmental budget of the government has a positive impact upon the economic growth. The study by Nguyen (2019) evaluated the impact of public spending upon the economic growth. A least squares method was used to evaluate the impact of state budget expenses on the basis of two main components; development investment expenditures and recurrent expenditures. The results of the study showed that the state budget has significant impacts upon the economy of Vietnam. In another study by Dinh Thanh and Canh (2019) the dynamic relation between the governmental spending, consumer spending and consumption patterns and economic growth were evaluated as well. A recent study by Divino et al. (2020) investigated the relationship among the optimal composition of governmental spending and size of the government and the economic growth from the perspective of Brazil. The study used the CES substitution production function in order to calculate the effective growth effects on the economy. In line with the model and method of the present study a nonlinear least squares method was used to estimate the coefficients. The used a balanced panel from 27 Brazilian states and evaluated the impact of exogenous factor technological progress as well. The state spending patterns and the government structure at the state level is in development and needs to focus on the development of policies that can optimize the growth of the individual states.

\section{Conclusion}

The basic aim of the present study was to evaluate the significance of the governmental spending and the government size on the growth of the provincial metrics of the Netherlands. The study employed a cobbDouglas production function and used the specifications of the literature to model a CES specification that evaluates the impact of these variables upon one another. The method of the nonlinear least squares was used to estimate the coefficients of the variables so that the procedural effect and the optimal impact of the governmental spending can be evaluated. The study used the data from the 12 provinces of Netherlands and the data from 2004-2014 was used. The estimations indicate that the level of private investments is greater than 64 percent and the governmental spending exceeds 85 percent in the estimated models, indicating that the provincial government is currently involved in spending a larger fraction of the budget in current spending rather than in investment. Thus, the results indicate positive outcomes for the economic growth in retrospect of the governmental size and spending patterns.

The present study presents some policy implications and recommendations for future researchers as well. The provincial government is more focused upon the current spending rather than focusing on expenditure and less attention is directed towards the investments in infrastructure and technology development of the sectors. The fiscal policy needs to focus on increasing the share of public expenditures and pursue optimal solutions for harmonizing the growth across the provinces of the country so that the economic growth can stimulated more effectively in the long run. The current study uses a small sample to evaluate the effects, thus it is recommended a larger sample be used in the future studies. It is recommended that a different methodology that could analyze the causal associations among the study variables be employed so that the effectiveness and long run relationships can be evaluated. 


\section{References}

Akram, V., \& Rath, B. N. (2019). Optimum government size and economic growth in case of Indian states: Evidence from panel threshold model. Economic Modelling, 95, 67-82.

Alarlough, A. N., Rabiei, M., \& Shoorkchal, J. M. (2017). Government size and economic growth in Iran. Paper presented at the XXIV Meeting of Public Economy.

Alimi, R. S. (2020). Public spending and economic welfare in ECOWAS countries: Does level of development matter? Germany: University Library of Munich.

Aparicio, S., Urbano, D., \& Audretsch, D. (2016). Institutional factors, opportunity entrepreneurship and economic growth: Panel data evidence. Technological Forecasting and Social Change, 102, 45-61.Available at: https://doi.org/10.1016/j.techfore.2015.04.006.

Ashwani, B., \& Sheera, V. P. (2017). Public spending and economic growth for Indian states. International Journal of Public Sector Performance Management, 3(3), 250-265.Available at: https://doi.org/10.1504/ijpspm.2017.085660.

Asimakopoulos, S., \& Karavias, Y. (2016). The impact of government size on economic growth: A threshold analysis. Economics Letters, 139, 65-68.Available at: https://doi.org/10.1016/j.econlet.2015.12.010.

Balaev, A. (2019). The structure of public spending and economic growth in Russia. Russian Journal of Economics, 5(2), 154176.Available at: https://doi.org/10.32609/j.ruje.5.38705.

Balsalobre-Lorente, D., Shahbaz, M., Roubaud, D., \& Farhani, S. (2018). How economic growth, renewable electricity and natural resources contribute to $\mathrm{CO} 2$ emissions? Energy Policy, 113, 356-367.Available at: https://doi.org/10.1016/j.enpol.2017.10.050.

Bergh, A., \& Henrekson, M. (2016). Government size and growth: A rejoinder. Journal of Economic Surveys, 30(2), 393396.Available at: https://doi.org/10.1111/joes.12103.

Biswas, A., \& Chaudhuri, S. (2018). Skill formation, public expenditure on education and wage inequality: Theory and evidence. Journal of Quantitative Economics, 16(2), 553-571.Available at: https://doi.org/10.1007/s40953-0170083-6.

Bouakez, H., Guillard, M., \& Roulleau-Pasdeloup, J. (2016). The optimal composition of public spending in a deep recession. University of Lausanne, Faculty of Business, Department of Economics.

Bove, V., Efthyvoulou, G., \& Navas, A. (2017). Political cycles in public expenditure: Butter vs guns. Journal of Comparative Economics, 45(3), 582-604.Available at: https://doi.org/10.1016/j.jce.2016.03.004.

Burlon, L. (2017). Public expenditure distribution, voting, and growth. Journal of Public Economic Theory, 19(4), 789810.Available at: https://doi.org/10.1111/jpet.12246.

Chen, J. (2020). Research on the relationship between government size and economic growth. Modern Economy, $11(2)$, 209219.Available at: https://doi.org/10.4236/me.2020.112018.

Cooper, T. J. (2020). An analysis of the impact of the size and type of government intervention on economic growth in South Africa. Doctoral Dissertation, North-West University (South Africa).

Das, P., \& Kar, S. (2016). Public expenditure, demography and growth: Theory and evidence from India. Institute of Labor Economics (IZA).

Davidson, R., \& MacKinnon, J. G. (2004). Econometric theory and methods (Vol. 5). New York: Oxford University Press.

Devarajan, S., Swaroop, V., \& Zou, H.-F. (1996). The composition of public expenditure and economic growth. Journal of Monetary Economics, 37(2), 313-344.Available at: https://doi.org/10.1016/0304-3932(96)01249-4.

Dinh Thanh, S., \& Canh, N. P. (2019). Dynamics between government spending and economic growth in China: An analysis of productivity growth. Journal of Chinese Economic and Business Studies, 17(2), 189-212.Available at: https://doi.org/10.1080/14765284.2019.1567069.

Divino, J. A., Maciel, D. T., \& Sosa, W. (2020). Government size, composition of public spending and economic growth in Brazil. Economic Modelling, 91, 155-166.Available at: https://doi.org/10.1016/j.econmod.2020.06.001.

Duasa, J. (2018). Government size and economic growth: Empirical study on organization of islamic cooperation countries. Journal of Social Science and Humanities, 1(6), 07-12.

Dudzeviciute, G., Simelyte, A., \& Liucvaitiene, A. (2018). Government expenditure and economic growth in the European Union countries. International Journal of Social Economics, 45(2), 372-386.Available at: https://doi.org/10.1108/ijse-12-2016-0365.

Duffy, J., \& Papageorgiou, C. (2000). A cross-country empirical investigation of the aggregate production function specification. Journal of Economic Growth, 5(1), 87-120.

Facchini, F., \& Seghezza, E. (2018). Public spending structure, minimal state and economic growth in France (1870-2010). Economic Modelling, 72, 151-164.Available at: https://doi.org/10.1016/j.econmod.2018.01.014.

Gnangoin, Y. T. B., Du, L., Assamoi, G., Edjoukou, A. J., \& Kassi, D. F. (2019). Public spending, income inequality and economic growth in Asian countries: A panel GMM approach. Economies, 7(4), 1-15.Available at: https://doi.org/10.3390/economies7040115.

Hadri, K. (2000). Testing for stationarity in heterogeneous panel data. The Econometrics Journal, 3(2), 148-161.Available at: https://doi.org/10.1111/1368-423x.00043.

Hajamini, M., \& Falahi, M. A. (2018). Economic growth and government size in developed European countries: A panel threshold approach. Economic Analysis and Policy, 58, 1-13.Available at: https://doi.org/10.1016/j.eap.2017.12.002.

Im, K. S., Pesaran, M. H., \& Shin, Y. (2003). Testing for unit roots in heterogeneous panels. Journal of Econometrics, 115(1), 53-74.Available at: https://doi.org/10.1016/s0304-4076(03)00092-7.

Keefer, P., Scartascini, C., \& Vlaicu, R. (2020). Voter preferences, electoral promises, and the composition of public spending. Electoral Promises, and the Composition of Public Spending (April 16, 2020).

Levin, A., Lin, C.-F., \& Chu, C.-S. J. (2002). Unit root tests in panel data: Asymptotic and finite-sample properties. Journal of Econometrics, 108(1), 1-24.Available at: https://doi.org/10.1016/s0304-4076(01)00098-7. 
Lupu, D., \& Asandului, M. (2017). The nexus between economic growth and public spending in Eastern European countries. Engineering Economics, 28(2), 155-161.Available at: https://doi.org/10.5755/jo1.ee.28.2.7734.

Magazzino, C., \& Forte, F. (2016). Government size and economic growth in Italy: A time-series analysis. European Scientific Journal, 12(7), 149-169.Available at: https://doi.org/10.19044/esj.2016.v12n7p149.

Meričková, B. M. (2017). Analysis of the relationship between the size and structure of public expenditure and socioeconomic development, Ekonomický časopis (Journal of Economics), 4(65), 320-333.

Michaillat, P., \& Saez, E. (2019). Optimal public expenditure with inefficient unemployment. The Review of Economic

Studies, 86(3), 1301-1331.Available at: https://doi.org/10.1093/restud/rdy030.

Nguyen, H. H. (2019). The role of state budget expenditure on economic growth: Empirical study in Vietnam. The Journal of Asian Finance, Economics and Business, 6(3), 81-89.Available at: https://doi.org/10.13106/jafeb.2019.vol6.no3.81.

Nirola, N., \& Sahu, S. (2019). The interactive impact of government size and quality of institutions on economic growthevidence from the states of India. Heliyon, 5(3), e01352.Available at: https://doi.org/10.1016/j.heliyon.2019.e01352.

Pesaran, M. H. (2007). A simple panel unit root test in the presence of cross-section dependence. Journal of Applied Econometrics, 22(2), 265-312.Available at: https://doi.org/10.1002/jae.951.

Pradhan, R. P., Dash, S., Maradana, R. P., Jayakumar, M., \& Gaurav, K. (2017). Insurance market density and economic growth in Eurozone countries: The Granger causality approach. Financial Innovation, 3(1), 1-24.Available at: https://doi.org/10.1186/s40854-017-0065-x.

Sanches, N. G., \& Rocha, F. (2010). Public and private state investments: Substitute or complementary "goods"? Applied Economics, 14(2), $211-223$.

Shittu, W. O., Hassan, S., \& Nawaz, M. A. (2018). The nexus between external debt, corruption and economic growth: Evidence from five SSA countries. African Journal of Economic and Management Studies, 9(3), 319-334.Available at: https://doi.org/10.1108/ajems-07-2017-0171.

Wadho, W., \& Ayaz, U. (2018). Government size and economic growth in an endogenous growth model with rent-seeking. Economics \& Politics, 30(1), 151-179. 